\title{
Effects of Different Swimming Intensities on the Bone Properties of the Tibia and Femur of Wistar Rats in which Knee Rheumatoid Arthritis was Induced
}

Efectos de las Diferentes Intensidades de la Natación en las Propiedades Óseas de la Tibia y Fémur de Ratas Wistar con Artritis Reumatoide Inducida en Rodillas

\author{
Alline Mardegan Mioto ${ }^{1,2}$; Robson Chacon Castoldi ${ }^{1,4}$; Regina Celi Trindade Camargo ${ }^{1,2}$; Thiago Alves Garcia ${ }^{3}$; \\ Daniel Fernando dos Reis ${ }^{4}$; Guilherme Akio Tamura Ozaki ${ }^{3}$; Iara Buriola Trevisan ${ }^{1,2}$; \\ Rodrigo Metzker Pereira Ribeiro ${ }^{4}$ \& José Carlos Silva Camargo Filho ${ }^{1,2}$
}

MIOTO, A. M.; CASTOLDI, R. C.; CAMARgO, R. C. T.; GARCIA, T. A.; DOS REIS, D. F.; OZAKI, G. A. T.; TREVISAN, I. B.; RIBEIRO, R. M. P. \& CAMARGO FILHO, J. C. S. C. Effects of different swimming intensities on the bone properties of the tibia and femur of Wistar rats in which knee rheumatoid arthritis was induced. Int. J. Morphol., 38(1):43-47, 2020.

SUMMARY: Rheumatoid arthritis (RA) is a disease triggered by environmental and genetic factors. Research suggests that physical exercise has benefits such as delaying functional disability. In vivo studies using experimental models of arthritis can provide useful information about these benefits. to analyze the effects that different intensities of aquatic physical exercise have on the proprieties of the bones in induced arthritis in knees of Wistar rats. Male Wistar adults rats $(n=20)$ were divided into 5 groups: Group Control Arthritis (GCA) n=4, Group control Placebo (GCP) n=4, Group Low Physical Activity (GB) n=4, Group Moderate Physical Activity $(\mathrm{GM}) \mathrm{n}=4$ and Group Intense Physical Activity $(\mathrm{GI}) \mathrm{n}=4$. The physical activity groups got an intra-articular injection of Zymosam on the right knee; the GCA received saline solution in the right knee; the GCP was submitted to the stress of the needle. The animals were submitted to aquatic activity for 30 minutes, 4 times a week for 5 weeks, and the intensity of the exercise was determined by a weight placed on their back: $\mathrm{GB}=1 \%, \mathrm{GM}=5 \%, \mathrm{GI}=15 \%$ of their body weight. It was observed that the group GB, and the groups that did not exercise GCA and GCP, gained more weight compared to the group GM. In relation to the bone mineral content of the tibia, there was a decrease in the GM group when compared to the GCP group, whereas in the tibial bone mineral density there was a decrease in the GM group compared to the GCP, GCA, GB. As for the area of the femur, the GI group presented an increase of it compared to the GB and GM groups. It is concluded that the high intensity exercises promote better results in bone properties.

KEY WORDS: Rheumatoid arthritis; Physical exercise; Wistar Rats; Arthritis induced in rats.

\section{INTRODUCTION}

RA is the most common inflammatory joint disease affecting around $0.5 \%$ to $1 \%$ of the population, thus determining an important social and economic cost, due to the degree of weakness and the increase in mortality (Suzuki et al., 1994).

AR is a symmetric polyarticular arthritis that mainly affects the small diarrodial joints of the hands and feet. In addition to the inflammation that occurs in the synovial membrane, an inflammatory exudate called pannus invades and destroys local joint structures. The synovial membrane is usually a relatively acellular structure (Suzuki et al.).
In RA, CD4 + T cells, B cells and macrophages infiltrate the synovial membrane and organize into discrete lymphoid aggregates with a germinal center (Huusko et al., 2001). As RA evolves, and joint destruction occurs, there is an evident decrease in joint mobility, as well as radiological evidence of bone erosion in a short period of time (Suzuki et al.).

The destruction of bone tissue by osteoclasts represents a pathological picture during inflammatory arthritis and results in bone pain and malformation (Seeling et al., 2013). Bone involvement in RA includes just-articu-

\footnotetext{
${ }^{1}$ Programa de Pós Graduação em Fisioterapia, Universidade Estadual Paulista “Júlio de Mesquita Filho”, Campus Presidente Prudente, São Paulo, Brazil.

${ }^{2}$ Departamento de Fisioterapia, Universidade Estadual Paulista “Júlio de Mesquita Filho”, Campus Presidente Prudente, São Paulo, Brazil.

${ }^{3}$ Departamento de Ciências da Cirurgia, Universidade Estadual de Campinas, São Paulo, Brazil.

${ }^{4}$ Departamento de Educação Física, Universidade do Oeste Paulista, Campus Presidente Prudente, São Paulo, Brazil.
} 
MIOTO, A. M.; CASTOLDI, R. C.; CAMARgO, R. C. T.; GARCIA, T. A.; DOS REIS, D. F.; OZAKI, G. A. T.; TREVISAN, I. B.; RIBEIRO, R. M. P. \& CAMARGO FILHO, J. C. S. C. Effects of different swimming intensities on the bone properties of the tibia and femur of Wistar rats in which knee rheumatoid arthritis was induced. Int. J. Morphol., 38(1):43-47, 2020.

lar osteopenia, and bone erosions. Osteoporosis is a very common finding in AR (Firestein, 2003), affecting $30 \%$ to $50 \%$ of the patients, resulting in a significant increase in the number of fractures (Hooyman et al., 1984; Huusko et al.).

In addition to cartilage destruction, marginal and subchondral bone erosions represent the radiographic characteristic of RA and contribute to joint dysfunction and progressive disability that occur in these patients Pereira \& Pereira, 2004).

Through aquatic physical exercise, patients with RA can improve aerobic fitness, muscle strength, joint mobility, functional fitness and even mood, without significant joint damage or worsening of the inflammatory process (Ferreira et al., 2008).

\section{MATERIAL AND METHOD}

Experimental design. The animals were subdivided into five groups (control of arthritis, sedentary control, low intensity exercise, moderate intensity exercise, and high intensity exercise) for the application of the respective training protocol. At the end of the respective protocols, the animals were euthanized to collect the material to be analyzed.

Animals. Twenty male Wistar rats, 60 days old, were obtained from the Central Unity of Presidente Prudente. These animals were kept in groups of three to five animals per cage, from the Biomedicine Department of Unoeste de Presidente Prudente, with an average temperature of $20 \pm 1{ }^{\circ} \mathrm{C}$ and a light / dark cycle of 12 hours, with free access to water and feed.

This work followed the principles of animal research and was approved by the animal ethics committee of the Unoeste under the protocol number 2358.

Arthritis Induction. For the induction of arthritis, initially the rats were anesthetized with intraperitoneal ketamine, dosed according to animal weight ( 1 to 1.5 microliters of ketamine per gram of weight). After anesthesia, the animal was submitted to intra-articular injection (ia) of $0.05 \mathrm{ml} / 100 \mathrm{~g}$ Zymosam (1mg / $50 \mathrm{~mL})$ in the right knee (Nonose et al., 2014). The animals in the control group arthritis (GCA) received saline solution in the right knee instead of Zymosan, and the animals in the placebo control group (GCP) were submitted only to the stress of the needle.

Training Model. To evaluate the effect of physical activity, the animals were submitted to aquatic activity. They were initially submitted to the aquatic activity in a collective tank with $15 \mathrm{~cm}$ of depth for 10 minutes, so they could familiarize with the environment and try to remain on the surface (Castoldi et al., 2017). After waiting for 15 minutes, the animals started the aquatic activity in a $40 \mathrm{~cm}$ deep tank for 30 minutes, where a load was attached to their back, through vests (Aleixo et al., 2019). The Exercise intensity was assessed by adding a load on the rats of each group (Ozaki et al., 2014). On the GB group loads of $1 \%$ of their body weight were added, in the GM group loads of $5 \%$ of their body weight were added and for the GI group loads of $15 \%$ of their body weight were added. The training protocol was repeated 4 times a week for 5 weeks.

In order to quantify the inflammatory edema, a nondigital caliper was used to measure the lateral mean diameter of the articular (AD) in each day, before and after physical activity. The data were presented as the difference between the means of the AD values measured daily before and after the aquatic exercise.

Surgical procedure. At the end of the 5th week of training, the Animals were euthanized by overdose of ketamine hydrochloride and xylazine intraperitoneally association (Léo et al., 2012), according to the ethical principles in animal research. After euthanasia, the tibia and right femur were removed by means of a longitudinal incision with removal of the skin and soft tissues, leaving the uncoated bones of the tissues at $-20{ }^{\circ} \mathrm{C}$ for further analysis of bone densitometry and assay three point bending mechanic (Ozaki et al.).

Mechanical Testing and Densitometry. The tibia and stored femurs were submitted to densitometry analysis using an Xray dual-emission densimeter (DXA), model DPX-Alpha, Lunar Corporation $®$, Madison, Wis, at the Faculty of Dentistry of Araçatuba - UNESP, using a special software developed for small animals (Ozaki et al.). The bones were submerged in a plastic container containing $2 \mathrm{~cm}$ of water to simulate soft tissue (in vivo). The middle thirds of the tibia and femur were delimited by the device, and this area covered by DXA $(5 \mathrm{~cm} \times 4 \mathrm{~cm})$. The densimeter laser was set above the center of the bone where image capture began. After the images were taken, the bones were analyzed using the manual analysis tool. The area wanted for analysis was delimited in the region of the middle third of the diaphysis of the tibia and femur and this was contoured to obtain the values of bone mineral content and bone mineral density.

The mechanical test of three-point flexion in each tibia was performed by means of a universal machine of mechanical tests EMIC@ 2000, that belongs to the Faculty of Dentistry of Araçatuba / UNESP, equipped with a load cell of $50 \mathrm{kgf}$ adjusted for the $20 \mathrm{kgf}$ scale. The device for testing three-point bending consists of two supports with a circular 
MIOTO, A. M.; CASTOLDI, R. C.; CAMARGO, R. C. T.; GARCIA, T. A.; DOS REIS, D. F.; OZAKI, G. A. T.; TREVISAN, I. B.; RIBEIRO, R. M. P. \& CAMARGO FILHO, J. C. S. C. Effects of different swimming intensities on the bone properties of the tibia and femur of Wistar rats in which knee rheumatoid arthritis was induced. Int. J. Morphol., 38(1):43-47, 2020.

profile of $3.5 \mathrm{~mm}$ in diameter located at the base of the machine and equidistant $20 \mathrm{~mm}$ and an actuator or cutter positioned between the supports, with the same shape and size of the supports, coupled to the moving part of the test machine by means of a load cell.

The tibia was positioned so that the measured reference point was aligned with the actuator, with a descent speed of 5 millimeters / minute. The bone was adjusted in such a way that it did not move during the test, having a zero initial pre-load. The assay continued, and the applied loads were monitored until the moment of rupture of the bone tissue. From then on, maximum strength and deformation values were obtained. The analyzed parameters were maximum force required to provoke bone fracture (Ozaki et al.).

Data analysis: The descriptive analysis was expressed as mean and standard deviation or median and interquartile range depending on the normality of the data tested by the Shapiro-Wilk test. The comparison between the groups was performed by the one-way ANOVA test with Tukey post test or Kruskal-Wallis test with Dunn's post test. For the comparison between the initial and final moments of the weight, student $\mathrm{t}$ test for dependent samples was applied. The SPSS 22.0 statistical program was used for all tests and the significance level adopted was $95 \%(\mathrm{p}<0.05)$.

\section{RESULTS}

Table I shows the animal body weight data, where no significant difference was observed between the four groups. However, at the end of the experiment, the animals of the GCP, GCA, GB groups presented increase in body weight (Table I).

Regarding bone density of the tibia after physical activity, BM had a decrease in BMC compared to GCP and a decrease in BMD compared to GCP, GCA and GB. For femoral bone density, there was a significant increase in the area in the GI compared to GB and GM (Fig. 1).
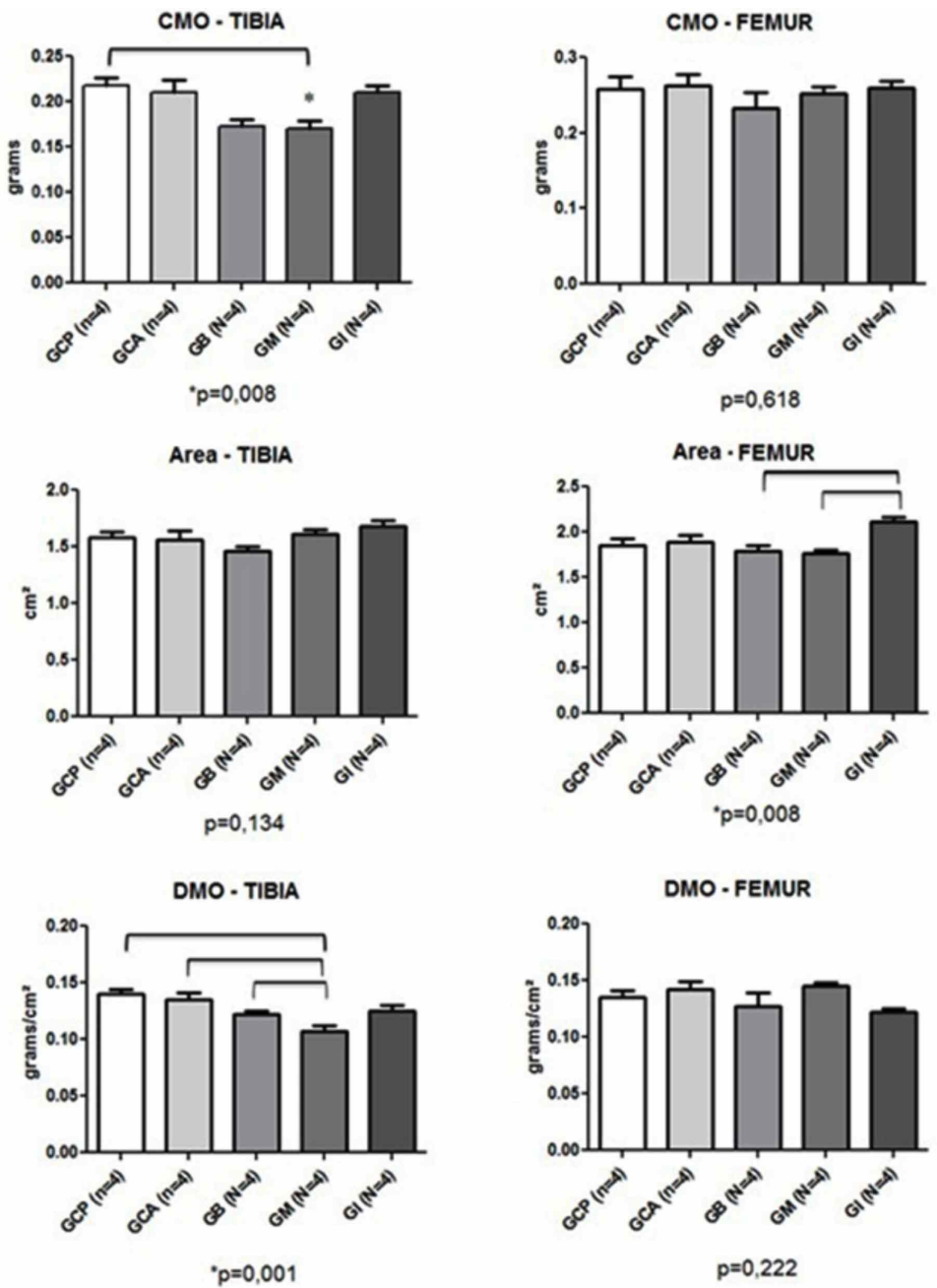

Fig. 1. Bone density difference between groups (CMO - TIBIA: GM different from GCP ( $\mathrm{p}=0,026)$ / DMO - TIBIA: GM different from GCP $(\mathrm{p}=0,001), \mathrm{GCA}(\mathrm{p}=0,002), \mathrm{GB}(\mathrm{p}=0,026) /$ Area - FEMUR: GI different from GB $(\mathrm{p}=0,014)$ e GM $(\mathrm{p}=0,008) ; * \mathrm{p}<0,05)$.

When we observed the mean and standard deviation values for the 3-point mechanical flexion test in the tibia of the animals (Fig. 2), we found a significant decrease in the Maximum Strength values of the GB groups $(58.99 \pm 11 ; \mathrm{p}$ $=0.043)$ and GM $(60.49 \pm 9 ; \mathrm{p}=0.027)$ compared to the GCP group $(82.5 \pm 5)$. Among the other groups there were no significant differences.

Table I. Body weight.

\begin{tabular}{|c|c|c|c|c|c|c|}
\hline & $\operatorname{GCP}(n=4)$ & $\operatorname{GCA}(n=4)$ & $\mathrm{GB}(\mathrm{n}=4)$ & GM $(n=4)$ & GI $(n=4)$ & $\mathrm{p}$-valor ${ }^{\mathrm{a}}$ \\
\hline Initial (g) & $254.5 \pm 26.9$ & $248.5 \pm 20.1$ & $266.8 \pm 28.0$ & $252.5 \pm 19.4$ & $267.3 \pm 19.6$ & 0.700 \\
\hline Final $(\mathrm{g})$ & $293.1 \pm 28.3$ & $291.8 \pm 33.3$ & $291.0 \pm 20.3$ & $276.5 \pm 16.7$ & $301.0 \pm 31.9$ & 0.708 \\
\hline $\mathrm{p}$-value $\mathrm{b}^{\mathrm{b}}$ & $0.002 *$ & $0.014 *$ & $0.019 *$ & 0.216 & 0.058 & \\
\hline
\end{tabular}

Data expressed as mean \pm standard deviation. GCP: placebo control group; GCA: arthritis control group; GB: low physical activity group; GM: moderate physical activity group; GI: intense physical activity group. a: one way ANOVA with Tukey post test; b: student $\mathrm{t}$ test; $* \mathrm{p}<0.05$. 


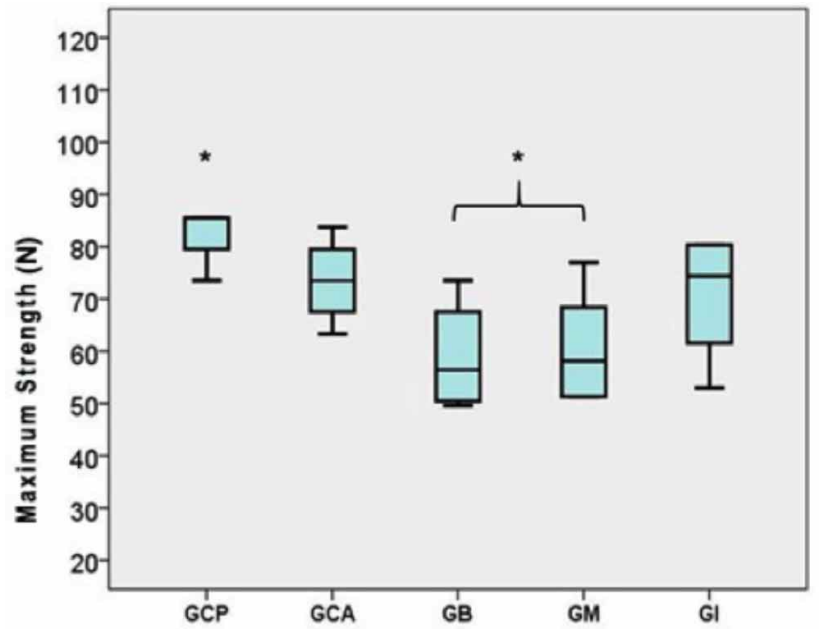

Fig. 2. Boxplot of the values found for Maximum Strength needed to fracture the tibia of the animals presented in Newtons $(\mathrm{N})$. *Shows the statistical difference between GB and GM groups that were significantly $(\mathrm{p}<0.05)$, lower than the GCP group.

\section{DISCUSSION}

The main objectives of this study were to evaluate the changes that different physical exercise intensities can cause in the tibia and femur of rats submitted to the induction of arthritis with Zymozan in the knee. It was observed that the GB and GM groups there was a decrease in BMC, compared to GI, for both the femur and the tibia. Regarding the bone area, in the GI group there was an increase in the area for both tibia and femur, when compared to GB and GM groups. In BMD, groups GB and GM again showed a decrease when compared to GI, GCA, GCP groups. In the mechanical assay, groups GB and GM it was observed that the maximum force to fracture the bones was smaller when compared to the groups, GCP.

The number of studies conducted to verify the effects of physical exercise in the treatment of RA patients has been increasing in the last decade. These studies indicate that the practice of physical exercise is indispensable (Albers et al., 2001). Even today there is no standard physical exercise protocol for RA treatment. However, in an attempt to achieve relief from the pain caused by this joint disease, often RA patients choose to assume physical inactivity most of the time.

This is extremely damaging when maintained beyond the acute phase of the disease as it may predispose to further joint injury due to decreased production of synovial fluid associated with prolonged immobilization and decreased bone mass (Caromano \& Nowotny, 2002; de Jong \& Vliet Vlieland, 2005). Hydrotherapy is a very used resource in the rehabilitation process in rheumatic patients, because it has some advantages due to the physical properties and physiological effects provided by the aquatic environment (Bilberg et al., 2005; Sacchelli et al., 2007).

It is often recommended for patients with arthritis as it provides benefits including reduction of edema, pain and overload on already injured joints (Külkamp et al., 2009). In one study, 115 RA patients were selected and submitted to a weekly 30-minute session of hydrotherapy or solo exercise (walking) for six weeks. When comparing the effects of physical exercises performed by RA patients on water and soil, it was concluded that immediately after the training performed in the water the individuals surveyed reported improvement in subjective perception of pain in a more expressive way than those who performed exercises out of water (Bertolini et al., 2009; Nonose et al.).

Some studies were carried out comparing the effects of soil and water exercises, and positive results were found for both categories. However, these results refer to pain, balance, muscle strength (Mattos et al., 2016). Concerning the bone health of the patient with RA nothing was found in the literature.

Based on this study, it can be stated that low-intensity aquatic exercises decrease bone density and are therefore detrimental to a patient who is physically inactive either because of pain or because of fear of aggravating the disease. However, it may be noted that high-intensity exercise did not decrease the force required for bone fracture of rats with arthritis when compared to lower intensities.

This is a viable exercise since it unites the benefits of hydrotherapy with the non-reduction of strength against fractures. Finally, the purpose of this study was to analyze the different intensities of physical exercise in induced arthritis in rats and to demonstrate which intensity brings (good or bad) results.

Although the study found no improvement in the bone characteristics of rats with arthritis, it can be concluded that high intensity physical exercise obtained better results in preventing a decrease in strength needed to fracture the bone. The study has limitations in that the process of induced arthritis is not as intense as a process of natural arthritis that takes longer to establish and affect the other structures around the joint, which makes it difficult to infer its effects in humans.

CONCLUSION. It can be concluded that the high intensity physical exercise practiced in aquatic environment can prevent the loss of bone strength caused by the absence of gravity found in the water in rats with Rheumatoid Arthritis induced in the knee. 
MIOTO, A. M.; CASTOLDI, R. C.; CAMARgO, R. C. T.; GARCIA, T. A.; DOS REIS, D. F.; OZAKI, G. A. T.; TREVISAN, I. B.; RIBEIRO, R. M. P. \& CAMARGO FILHO, J. C. S. C. Effects of different swimming intensities on the bone properties of the tibia and femur of Wistar rats in which knee rheumatoid arthritis was induced. Int. J. Morphol., 38(1):43-47, 2020.

ACKNOWLEDGMENTS. The authors are grateful to the Brazilian Agency of Resources for Higher Education Personnel (CAPES) for supporting the development of this study.

MIOTO, A. M.; CASTOLDI, R. C.; CAMARgO, R. C. T.; GARCIA, T. A.; DOS REIS, D. F.; OZAKI, G. A. T.; TREVISAN, I. B.; RIBEIRO, R. M. P. \& CAMARGO FILHO, J. C. S. C. Efectos de las diferentes intensidades de la natación en las propiedades óseas de la tibia y fémur de ratas Wistar con artritis reumatoide inducida en rodillas. Int. J. Morphol., 38(1):43-47, 2020.

RESUMEN: La investigación sugiere que el ejercicio físico tiene beneficios como retrasar la discapacidad funcional de la artritis reumatoide. Los estudios in vivo que utilizan modelos experimentales de artritis pueden proporcionar información útil sobre estos beneficios. Se analizaron los efectos de las intensidades del ejercicio físico acuático sobre las propiedades de los huesos, en la artritis inducida en las rodillas de ratas Wistar. Las ratas Wistar macho adultas $(n=20)$ se dividieron en 5 grupos: grupo de control artritis (ACG) $n=4$, grupo control placebo (CGP) $n=4$, grupo de actividad física baja $(\mathrm{GB}) \mathrm{n}=4$, grupo de actividad física moderada $(\mathrm{GM}) \mathrm{n}=$ 4 y grupo de actividad física intensa $(\mathrm{GI}) \mathrm{n}=4$. Los grupos de actividad física recibieron una inyección intraarticular de Zymosam en la rodilla derecha; el GCA recibió solución salina en la rodilla derecha; el CGP fue sometido a la tensión de una aguja. Los animales fueron sometidos a actividad acuática durante 30 minutos, 4 veces a la semana durante 5 semanas, y la intensidad del ejercicio se determinó mediante un peso colocado sobre su espalda: $\mathrm{GB}=1 \%, \mathrm{GM}=5 \%$, $\mathrm{GI}=15 \%$ de su peso corporal. Se observó que el grupo GB, y los grupos que no ejercitaron GCA y CGP, ganaron más peso en comparación con el grupo GM. En relación con el contenido mineral óseo de la tibia, hubo una disminución en el grupo GM en comparación con el grupo GCP, mientras que en la densidad mineral del hueso tibial hubo una disminución en el grupo GM en comparación con el GCP, GCA, GB. En cuanto al área del fémur, el grupo GI presentó un aumento en comparación con los grupos GB y GM. En conclusión el ejercicio de alta intensidad promueve mejores resultados en las propiedades óseas.

PALABRAS CLAVE: Artritis reumatoide; Ejercicio físico; Ratas Wistar; Artritis inducida en ratas.

\section{REFERENCES}

Albers, J. M.; Paimela, L.; Kurki, P.; Eberhardt, K. B.; Emery, P.; van 't Hof, M. A.; Schreuder, F. H.; Leirisalo-Repo, M. \& van Riel, P. L. Treatment strategy, disease activity, and outcome in four cohorts of patients with early rheumatoid arthritis. Ann. Rheum. Dis., 60(5):453$8,2001$.

Aleixo, P. H.; Santos, L. S.; Ozaki, G. A. T.; Garcia, T. A.; Zanuto, E. A. C.; Camargo, R. C. T.; Camargo Filho, J. C. S. \& Castoldi, R. C. Effects of consumption of soft drinks on the muscular morphology of animals submitted to concurrent training. Int. J. Morphol., 37(2):671-6, 2019.

Bertolini, S. M. M. G.; de Oliveira, P. D.; Cararo, D. C. \& Tamyozo, M. F. Resposta das estruturas articulares do joelho de ratos pós-imobilização. Ciênc. Saúde, 2(1):8-15, 2009.
Bilberg, A.; Ahlmén, M. \& Mannerkorpi, K. Moderately intensive exercise in a temperate pool for patients with rheumatoid arthritis: a randomized controlled study. Rheumatology (Oxford), 44(4):502-8, 2005.

Caromano, F. A. \& Nowotny, J. P. Princípios físicos que fundamentam a hidroterapia. Fisioter. Bras., 3(6):1-9, 2002.

Castoldi, R. C.; Ozaki, G. A. T.; Giometti, I. C.; Camargo, R. C. T.; Koike, T. E.; Garcia, T. A.; Camargo Filho, J. C. S. \& Belangero, W. D. Morphometric study of muscle fibers in rats submitted to strength training and growth hormone. Int. J. Morphol., 35(2):472-8, 2017.

de Jong, Z. \& Vliet Vlieland, T. P. Safety of exercise in patients with rheumatoid arthritis. Curr. Opin. Rheumatol., 17(2):177-82, 2005.

Ferreira, L. R. F.; Pestana, P. R.; de Oliveira, J. \& Mesquita-Ferrari, R. A. Efeitos da reabilitação aquática na sintomatologia e qualidade de vida de portadoras de artrite reumatóide. Fisioter. Pesqui., 15(2):136-41, 2008.

Firestein, G. S. Evolving concepts of rheumatoid arthritis. Nature, 423(6937):356-61, 2003.

Hooyman, J. R.; Neiton, L. J. 3rd; Nelson, A. M.; O'Fallon, W. M. \& Riggs, B. L. Fractures after rheumatoid arthritis. A population-based study. Arthritis Rheum., 27(12):1353-61, 1984.

Huusko, T. M.; Korpela, M.; Karppi, P.; Avikainen, V.; Kautiainen, H. \& Sulkava, R. Threefold increased risk of hip fractures with rheumatoid arthritis in Central Finland. Ann. Rheum. Dis., 60(5):521-2, 2001.

Külkamp, W.; Dario, A. B.; Gevaerd, M. S. \& Domenech, S. C. Artrite reumatóide e exercício físico: Resgate histórico e cenário atual. Rev. Bras. Ativ. Fís. Saúde, 14(1):55-64, 2009.

Léo, J. A.; da Cunha, A.; de Oliveira, E. F.; \& Prado, R. P. Effect of low-level laser (GaAs, 904HM) for bone repair on fractures in rats. Rev. Bras. Ortop., 47(2):235-40, 2012.

Mattos, F.; Leite, N.; Pitta, A. \& Bento, P. C. Effects of aquatic exercise on muscle strength and functional performance of individuals with osteoarthritis: a systematic review. Rev. Bras. Reumatol. Engl. Ed., 56(6):530-42, 2016

Nonose, N.; Pereira, J. A.; Machado, P. R.; Rodrigues, M. R.; Sato, D. T. \& Martinez, C. A. Oral administration of curcumin (Curcuma longa) can attenuate the neutrophil inflammatory response in zymosan-induced arthritis in rats. Acta Cir. Bras., 29(11):727-34, 2014.

Ozaki, G. A. T.; Koike, T. E.; Castoldi, R. C.; Garçon, A. A. B.; Kodama, F. Y.; Watanabe, A. Y.; Job, A. W.; Louzada, M. J. Q.; Camargo, R. C. T. \& Camargo Filho, J. C. S. Efeitos da remobilização por meio de exercício físico sobre a densidade óssea de ratos adultos e idosos. Motriz, 10(3):718, 2014.

Pereira, I. A. \& Pereira, R. M. R. Osteoporose e erosões osseas focais na artrite reumatóide: da patogênese ao tratamento. Rev. Bras. Reumatol., 44(5):347-54, 2004.

Sacchelli, T.; Accacio, L. M. P.; Radl, A. L. M.; Monteiro, C. G. \& Gava, M. V. Fisioterapia aquática. São Paulo, Manole, 2007.

Seeling, M.; Hillenhoff, U.; David, J. P.; Schett, G.; Tuckermann, J.; Lux, A. \& Nimmerjahn, F. Inflammatory monocytes and Fcg receptor IV on osteoclasts are critical for bone destruction during inflammatory arthritis in mice. Proc. Natl. Acad. Sci. U. S. A., 110(26):10729-34, 2013.

Suzuki, A.; Ohosone, Y.; Obana, M.; Mita, S.; Matsuoka, Y.; Irimajiri, S. \& Fukuda, J. Cause of death in 81 autopsied patients with rheumatoid arthritis. J. Rheumatol., 21(1):33-6, 1994.

\section{Corresponding author:}

Alline Mardegan Mioto

Rua Roberto Simonsen, 305

Centro Educacional - P. Prudente/SP - CEP 19060-900

Email: allinemioto@gmail.com

Received: 08-06-2019 Accepted: 20-08-2019 